\title{
Pembuatan Plastik Biodegradable dari Tongkol Jagung: Studi Kasus Desa Dawuhan Mangli, Kecamatan Sukowono, Jember, Indonesia
}

\author{
Ari Susanti, Sartika D. Purwandari, Rendra S. Aji, Fanteri A. D. Suparno \\ Faculty of Engineering, Universitas Jember \\ ari.susanti@unej.ac.id
}

\begin{abstract}
Abstrak
Plastik pada umumnya dibuat dari bahan polimer sinetik yang berasal dari minyak bumi. Plastik sintetik mempunyai karakteristik yang sukar terurai sehingga sangat berpotensi untuk mencemari lingkungan. Upaya yang dilakukan untuk mengurangi pencemaran lingkungan yaitu dengan mengalihkan penggunaan plastik biasa menjadi plastik biodegradable. Dawuhan Mangli merupakan salah satu desa di Jember yang mempunyai hasil pertanian utama yaitu jagung. Komoditi jagung hasil panen biasanya diambil bijinya saja sehingga menghasilkan sisa yang berupa tongkol jagung. Tongkol jagung mengandung serat selulosa sehingga bisa dijadikan polimer alami sebagai bahan baku pembuatan plastik biodegradable. Pada pengabdian ini dilakukan pembuatan plastik biodegradable dari limbah tongkol jagung dengan dua tahap yakni pre-treatment dan mainprocess. Pre-treatment dilakukan dengan melakukan tindakan secara fisika pada tongkol jagung sehingga menjadi serbuk tongkol jagung berukuran 80 mesh. Sedangkan dalam tahap main-proces, serbuk tongkol jagung diproses dengan melakukan pencampuran dengan bahan biopolimer lain, pengadukan hingga suhu tertentu. Kemudian hasilnyan dituang dalam cetakan dan dikeringkan dalam oven. Hasil yang didapat adalah berupa bijih plastik/lembaran plastik.
\end{abstract}

Kata Kunci: biodegradable, plastik, tongkol jagung, selulosa

\begin{abstract}
In general, plastic is made by synthetic polymer from crude oil. Synthetic plastic has characteristic undegradable, that is potentially to pollute an environmetal. The way to reduce the environmental pollution is converting the synthetic plastic to biodegradable plastic. Dawuhan Mangli is one of village in Jember area which has corn agriculture main commodity. Corn from harvest normally is only beads taken with corncob left. Corncob is containing cellulose as an material source to produce nature polymer as raw material to produce biodegradable plastic. This community service is conducted by produce biodegradable plastic from corncob waste using two stages, pre-treatment and mainprocess. Pre-treatment is done by doing physical actions on corn cobs so that it becomes 80 mesh corncobs powder. While in the main process, corncobs powder is processed by mixing with other biopolymer materials, stirring to a certain temperature. Then the results are poured in a mold and dried in the oven. The results obtained are plastic or plastic sheets.
\end{abstract}

Keywords: biodegradable, plastic, corncobs, cellulose 


\section{PENDAHULUAN}

Indonesia merupakan negara dengan jumlah penduduk ke empat terbesar di dunia dengan total jumlah penduduk mencapai 264 juta (bps.go.id). Dengan tingkat populasi yang tinggi ini menjadikan Indonesia memiliki beragam masalah yang terkait dengan isu lingkungan. Salah satu aspek lingkungan yang yang memiliki urgensi yang harus diperhatikan adalah aspek limbah berupa plastik.

Plastik merupakan salah satu bahan yang banyak dipakai oleh manusia dalam kehidupan sehari-hari. Karakteristik plastik yang murah, kuat, dan ringan menjadikan plastic banyak dipakai dalam kehidupan sehari-hari. Plastik yang umum digunakan hari ini adalah berasal dari polimer sintetis dari minyak bumi (Aripin dkk., 2017). Kelemahan dari plastik dengan bahan polimer sintetis adalah jumlah yang terbatas dan sulit untuk didaur ulang.

Sampah plastik merupakan limbah yang sulir terurai secara alamiah oleh alam. Limbah plastik dalam jumlah besar akan mempengaruhi kondisi lingkungan yang ada / disekitarnya. Karena limbah plastik terbuat dari bahan polimer sintetis, proses penguraiannya berlangsung dalam kurun waktu yang lama.

Pengelolaan sampah khususnya untuk limbah plastik dilakukan secara tradisional, yaitu membakar sampah. Proses pengolahan ini memiliki dampak negatif berupa perncemaran udara serta meningkatkan kerentanan terjadinya penyakit infeksi saluran pernapasan (ISPA). Pengolahan sampah yang lain adalah dengan melakukan penimbunan sampah. Dengan munculnya berbagai masalah lingkungan akibat plastik, maka diperlukan alternatif bahan plastik yang ramah lingkungan dan mampu terurai (Purwaningrum, 2016).

Biodegradable plastik atau Bioplastik adalah plastik yang tersusun dari polimer alamiah yang mampu terdegradasi baik oleh mikroorganisme maupun cuaca (Aripin dkk., 2017). Bioplastik dapat dibuat dari bahan alami pati dicampur dengan gelatin atau selulosa atau biopolimer lainnya. Bahan alami pati bisa didapatkan dari hasil pertanian (Mustafa dkk., 2018). Pada kegiatan pengabdian masyarakat ini, bioplastik berbahan dasar dari tongkol jagung diharapkan mampu mengurangi dampak kerusakan lingkungan dan menambah pendapatan masyarakat sekitar.

Jagung merupakan komoditi pangan sekunder yang menjadi penyangga dan pelengkap komoditi pangan utama yakni padi (Sirappa, 2003). Berdasarkan statistik produksi tanaman pangan Indonesia tahun 2010-2014, produksi jagung rata-rata 18.483.727 ton/tahun. Jagung saat ini merupakan komoditi strategis kedua di beberapa daerah karena menjadi bahan makanan pokok. Jagung juga memiliki peranan penting dalam pengembangan industri pangan, pakan ternak, dan bahan baku industri yang lain. Jawa Timur merupakan sentra produksi jagung terbesar dengan luas areal 1.270.388 ha atau 26,88\% luas areal keseluruhan produksi jagung Nasional (Departemen Pertanian, 2013). Bahkan menurut data 
BPS Provinsi Jawa Timur tahun 2017 diperoleh data bahwa usaha tani jagung menyebar di beberapa wilayah kabupaten, salah satunya Kabupaten Jember sebanyak 471.285 ton. Wilayan di Kabupaten Jember yang merupakan penghasil tanaman jagung, salah satunya yakni Desa Dawuhan Mangli, Kecamatan Sukowono.

Di Desa Dawuhan Mangli, jagung menjadi salah satu sumber daya pertanian yang sangat berpotensi namun belum optimal diberdayakan. Hingga saat ini, jagung hasil pertanian desa hanya sekedar diperjualbelikan dalam bentuk jagung mentah begitu saja. Selain itu, pemanfaatan yang ada masih terbatas, misalnya batang dan daun jagung banyak digunakan sebagai pakan ternak serta biji jagung dimanfaatkan sebagai sumber bahan makanan untuk manusia dan pakan ternak. Padahal hampir semua bagian jagung bisa dimanfaatkan, baik itu bagian batang, daun, kulit, biji jagung dan bonggol atau tongkol jagung. Salah satu bagian jagung yang bisa dimanfaatkan adalah bonggol/tongkol jagung. Tongkol jagung merupakan sisa bagian dari biji jagung yang sudah dimanfaatkan penduduk desa Dawuhan Mangli sebagai bahan pangan manusia maupun bahan pakan ternak.

Tongkol jagung menjadi sampah atau limbah, yang oleh penduduk desa dibuang begitu saja. Padahal tongkol jagung bisa dikelola dan dimanfaatkan menjadi produk bernilai guna lebih tinggi yakni sebagai bahan bioplastik atau plastik biodegradable. Pengembangan bahan plastik dari tongkol jagung memang masih sangat terbatas. Pada dasarnya tongkol jagung banyak mengandung bahan selulosa yang bermanfaat untuk membuat senyawa kimia pada bahan plastik. Dalam tongkol jagung banyak mengandung beberapa senyawa selulosa yang bisa mengikat kimia plastik dengan baik. Ide untuk menggantikan bahan selulosa plastik dengan tongkol jagung sangat baik karena bisa menjadi bahan plastik yang ramah terhadap lingkungan. Masyarakat perlu diberikan sosialisasi dan inisiasi tentang bagaimana cara mengelola dan mengolah sampah atau limbah tongkol jagung yang jumlahnya melimpah sehingga mampu mengangkat nilai ekonomis dari sampah atau limbah tersebut serta dapat bermanfaat bagi masyarakat sekitar.

\section{METODOLOGI}

Dalam melaksanakan kegiatan pengabdian program pengembangan desa binaan, metodologi dalam pembuatan plastik biodegradable terbagi menjadi 2 tahap yakni pre-treatment dan main-process.

A. Pre-Treatment 
Dalam tahap pre-teratment, yang pertama harus dilakukan yakni menjemur tongkol jagung sekitar 4 hari. Kemudian tongkol jagung dicacah kasar. Setelah dicacah, tongkol jagung digiling agar ukurannya lebih kecil. Selanjutnya tongkol jagung diblender 3 kali kemudian diayak dan didapatkan serbuk tongkol jagung berukuran 80 mesh.

\section{B. Main Process}

Pada proses utama dalam metode pembuatan plastik biodegradable dari tongkol jagung dikukan dengan melalui tahapan antara lain serbuk tongkol jagung ditambah aquades direbus di atas kompor listrik, diaduk - aduk hingga suhu tertentu, selanjutnya hasil rebusan serbuk tongkol jagung disaring dan didapatkan larutan pati, larutan pati kemudian ditambah gliserol, gelatin, dan asam asetat diaduk hingga homogen. Larutan tersebut diberi pewarna lalu hasil larutan disaring dan dituangkan pada cetakan. Selanjutnya didiamkan selama beberapa menit di suhu ruang kemudian dimasukkan oven selama beberapa menit dengan suhu tertentu.

\section{HASIL DAN PEMBAHASAN}

Kegiatan pengabdian program pengembangan desa binaan ini terbagi menjadi 3 sesi. Sesi 1 berupa kegiatan sosialisasi tentang pengelolaan dan pemilahan sampah serta pengelolaan dan pengolahan sampah tongkol jagung menjadi produk plastik biodegradable bertujuan untuk memberikan pengetahuan kepada masyarakat Desa Dawuhanmangli, Kecamatan Sukowono, Kabupaten Jember tentang cara mengelola dan memilah sampah; mengelola dan mengolah sampah tongkol jagung menjadi produk plastik biodegradable yang bisa menjadi peluang dalam meningkatkan perekonomian warga setempat. Kegiatan ini dilaksanakan pada hari Selasa tanggal 23 Juli 2019, ditunjukkan oleh Gambar 1.

Sedangkan kegiatan pelatihan mekanisme pembuatan plastik biodegradable dibagi menjadi sesi 3 dan sesi 4 yang dilaksanakan dalam 2 hari yakni pada Rabu tanggal 07 Agustus 2019 dan pada Kamis tanggal 08 Agustus 2019. Kegiatan pada sesi kedua yakni demonstrasi mekanisme pembuatan plastik biodegradable yang dipandu oleh tim pengabdian yang ditunjukkan pada Gambar 2. Sedangkan pada sesi ketiga masyarakat diberikan kesempatan untuk mepraktekkan langsung mekanisme pembuatan plastik biodegradable dengan dibimbing oleh tim pengabdian yang ditunjukkan pada Gambar 3. 


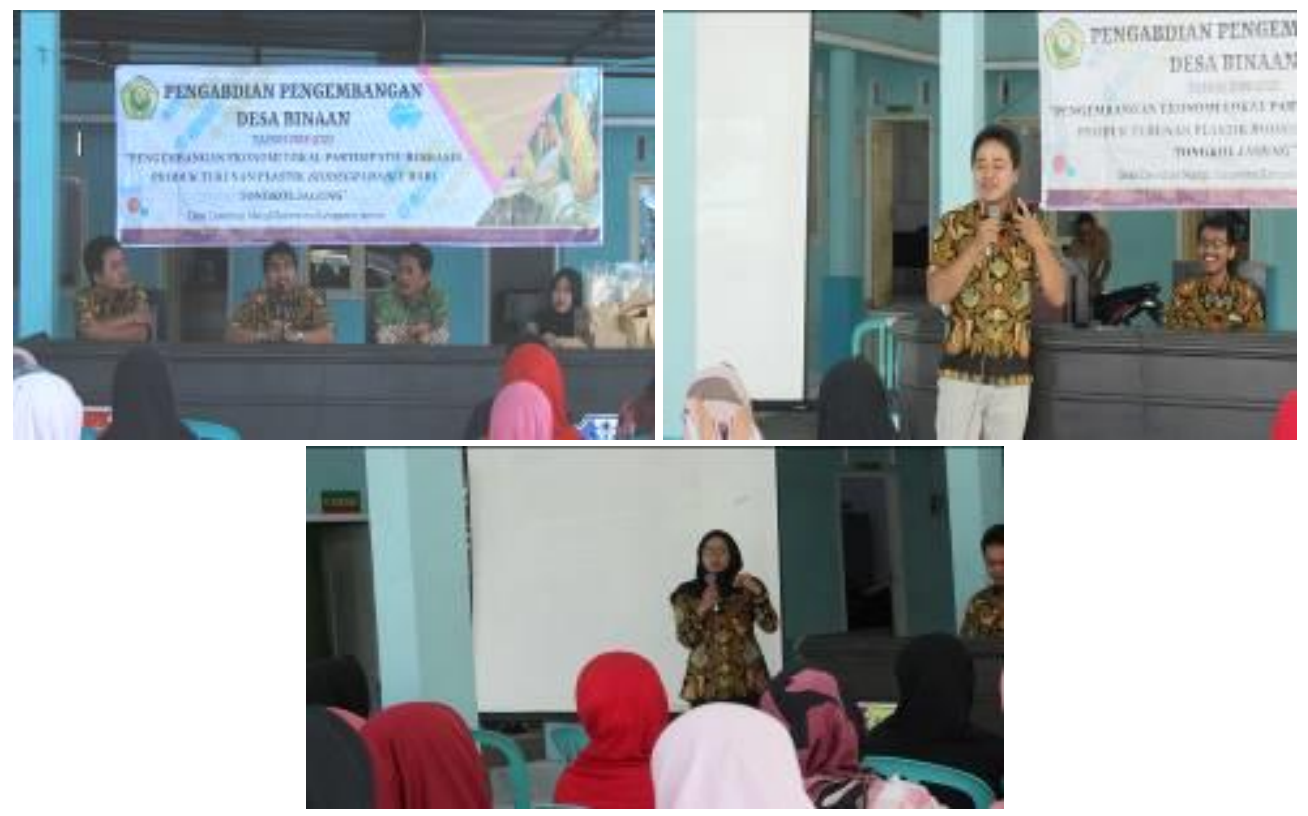

Gambar 1. Sosialisasi pengelolaan dan pemilahan sampah serta pengelolaan dan pengolahan sampah tongkol jagung menjadi produk plastik biodegradable

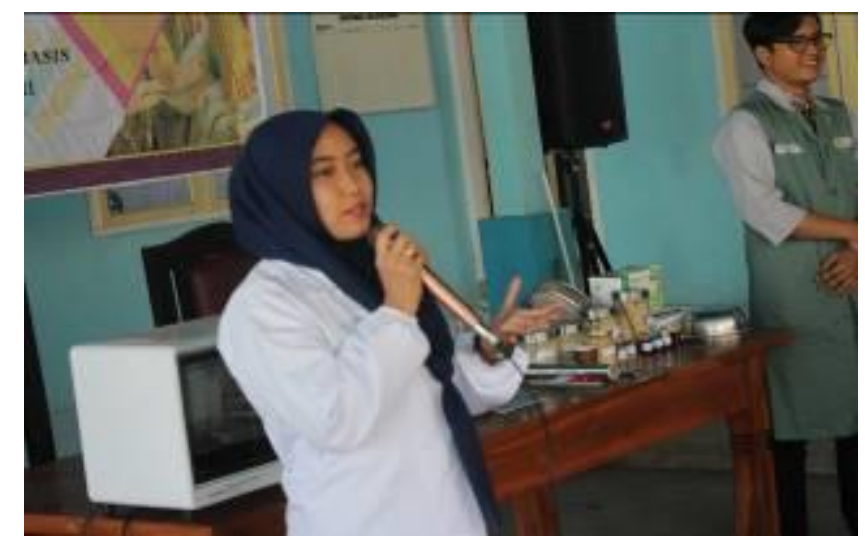

Gambar 2. Tim pengabdian memberi penjelasan tahapan pembuatan plastik biodegradable pada sesi 2 


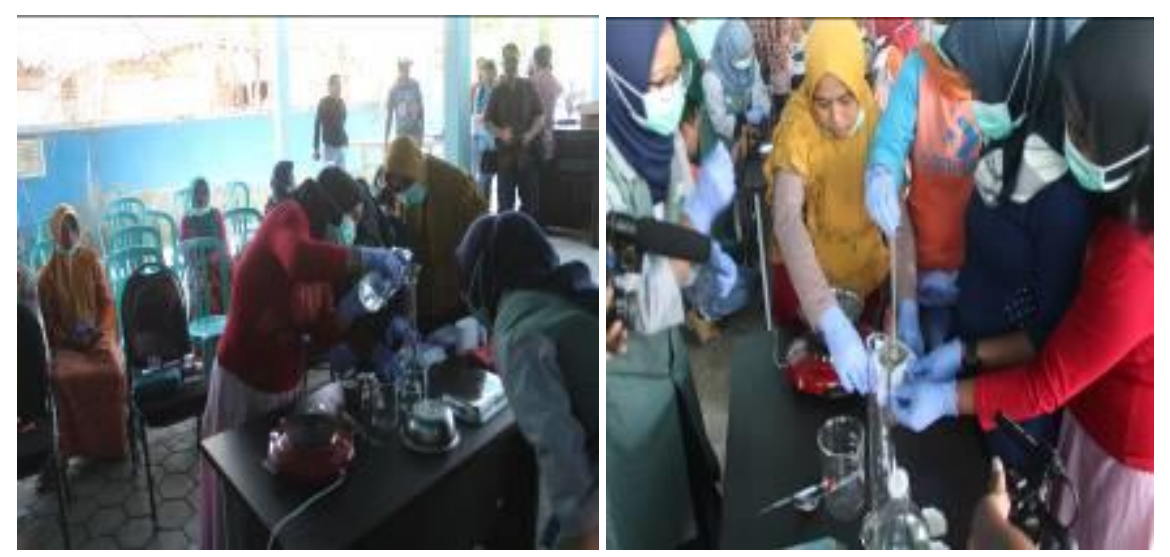

Gambar 3. masyarakat mempraktekkan langsung mekanisme pembuatan pembuatan plastik biodegradable

\section{KESIMPULAN DAN SARAN}

Kesimpulan dari Program Pengembangan Desa Binaan ini antara lain bahwa limbah tongkol jagung dapat dikelola sehingga tidak hanya menjadi limbah yang mengganggu estetika lingkungan, tetapi menjadi suatu produk yang memiliki nilai tambah. Selain itu, limbah tongkol jagung juga dapat dimanfaatkan sebagai plastik biodegradable.

Saran untuk kegiatan pengabdian ini adalah perlu dilakukan kerja sama lebih lanjut dengan pemerintah Desa Dawuhan Mangli dalam mewujudkan produk plastik biodegradable yang siap dipasarkan untuk meningkatkan perekonomian masyarakat desa.

\section{DAFTAR PUSTAKA}

\section{Artikel Jurnal:}

Aripin, S., Saing, B., \& Kustiyah, E. (2017). Studi pembuatan bahan alternatif plastik biodegradable dari pati ubi jalar dengan plasticizer gliserol dengan metode melt intercalation. Jurnal Teknik Mesin Mercu Buana, 6(2), 79-84.

Purwaningrum, P. (2016). Upaya mengurangi timbulan sampah plastik di lingkungan. Indonesian Journal of Urban and Environmental Technology, 8(2), 141-147.

Mostafa, N. A., Farag, A. A., Abo-dief, H. M., \& Tayeb, A. M. (2018). Production of biodegradable plastic from agricultural wastes. Arabian journal of chemistry, 11(4), 546-553. 
Sirappa, M. P. (2003). Prospek pengembangan sorgum di Indonesia sebagai komoditas alternatif untuk pangan, pakan, dan industri. Jurnal Litbang Pertanian, 22(4), 133-140.

\section{Sumber Internet:}

BPS. "Jumlah Penduduk Indonesia", online : https://www.bps.go.id/subject/12 /kependudukan.html (2019).

Elvianora, Rahmawati. 2014. Tongkol Jagung meningkatkan bobot badan ternakruminansial00gramperhari.http://peternakan.litbang.pertanian.go.id/engl ish/index.php?option=com_content\&\&iew=article\&\&id=4567:tongkoljagungmeningkatkan-bobot-badan-

100graperhariłsthash.hjhILBNx.dpuf(diakses pada tanggal 14 November 2015 : pukul 13.00 WIB)

Halimi,

Zaleha.

2006.

Botani.

http://zalehahalimi.tripod.com/pokok_jagung.htm(diakses pada tanggal : 2 November 2015, pukul 20.00WIB).Herawati,W.D.2016.Budidaya Tembakau. Trans Idea Publishing. Yogyakarta. 